\title{
HEALTHCARE MANAGEMENT OF TUBERCULOSIS: INTEGRATING A TEACHING HOSPITAL INTO PRIMARY HEALTH CARE ${ }^{1}$
}

\author{
Ana Paula Cunha Coelho², Liliana Muller Larocca ${ }^{3}$, Maria Marta Nolasco Chaves ${ }^{4}$, Jorge Vinicius Cestari Felix ${ }^{5}$, \\ Elizabeth Bernardino ${ }^{6}$, Sandra Mara Alessi ${ }^{7}$
}

\begin{abstract}
${ }^{1}$ Paper deriving from the thesis - Tuberculosis Care Management: integrating a Teaching Hospital into Primary Health Care, presented to the Programa de Pós-Graduação em Enfermagem - Mestrado Profissional, Universidade Federal do Paraná (UFPR), in 2014.

2 M.Sc. in Nursing. Administrative technician, UFPR. Curitiba, Paraná. Brazil. E-mail: ana.anacoelho@gmail.com

${ }^{3}$ Ph.D. in Education. Professor, UFPR. Curitiba, Paraná. Brazil. E-mail: liliana@ufpr.br

${ }^{4}$ Ph.D. in Sciences. Professor, UFPR. Curitiba, Paraná. Brazil. E-mail: mnolascochaves@gmail.com.br

${ }^{5}$ Ph.D. in Sciences. Professor, UFPR. Curitiba, Paraná. E-mail: jvcfelix@ufpr.br

${ }^{6}$ Ph.D. in Nursing. Professor, UFPR. Curitiba, Paraná. Brazil. E-mail: elizabeth.bernardino@hotmail.com

7 Ph.D. in Public Health. Professor, UFPR. Curitiba, Paraná. Brazil. E-mail: sandramalessi@gmail.com
\end{abstract}

\begin{abstract}
Qualitative, exploratory and interventionist case study at a teaching hospital of Paraná, with the objective of proposing a Tuberculosis Healthcare Management model focused on the hospital discharge, with a view to comprehensive care for patients with tuberculosis. Interviews were conducted with key informants (17 subjects), using the Theory of Nursing Praxis Intervention in Collective Health as the theoretical and methodological framework, with its three interdependent dimensions used as analytical categories. Weakness was revealed in the protocols for hospitalized patient care, insufficient integration between levels of care and the need for direct communication between the hospital and primary care nurses. In view of this result, a Healthcare Management Model, expressed as a flow of care with matrix support, nursing consultation and phone contact between nurses. The implementation of this model will lead to greater integration between the levels of care, permitting improvements in patient monitoring with greater probability of treatment compliance. DESCRIPTORS: Tuberculosis. Nursing. Public health. Integrality in health. Health management.
\end{abstract}

\section{GESTÃO DO CUIDADO DA TUBERCULOSE: INTEGRANDO UM HOSPITAL DE ENSINO À ATENÇÃO PRIMÁRIA À SAÚDE}

RESUMO: Pesquisa de cunho qualitativo, exploratório e intervencionista em hospital universitário do Paraná, com o objetivo de propor um modelo de Gestão do Cuidado da Tuberculose voltado à alta hospitalar, buscando cuidado integral ao portador dessa doença. Foram realizadas entrevistas com informantes-chave (17 sujeitos), tendo a Teoria da Intervenção Práxica de Enfermagem em Saúde Coletiva como referencial teórico-metodológico, com suas três dimensões interdependentes, utilizadas como categorias analíticas. Ficou evidenciado fragilidade nos protocolos voltados ao cuidado do doente internado, insuficiente integração entre níveis de atenção e necessidade de comunicação direta entre enfermeiros do hospital e da atenção primária. Diante desse resultado, foi proposto modelo de Gestão do Cuidado, traduzido em fluxo de atendimento com apoio matricial, consulta de enfermagem e contato telefônico entre enfermeiros. Acredita-se que a implantação desse modelo trará maior integração entre os níveis de atenção, melhora no processo de acompanhamento do doente com maior probabilidade de adesão ao tratamento.

DESCRITORES: Tuberculose. Enfermagem. Saúde pública. Integralidade em saúde. Gestão em saúde.

\section{GESTIÓN DEL CUIDADO DE LA TUBERCULOSIS: INTEGRANDO UNO HOSPITAL DE DOCENTE A LA ATENCIÓN PRIMARIA DE SALUD}

\begin{abstract}
RESUMEN: Investigación cualitativa, exploratoria e intervencionista en un hospital universitario del Paraná, con el objetivo de proponer un modelo de Gestión del Cuidado de la Tuberculosis centrada en las altas de hospital, en busca de la atención integral de los pacientes con tuberculosis. Se realizaron entrevistas con informantes clave (17 sujetos) con la Teoría de Enfermería Praxis Intervención en Salud Colectiva como marco teórico y metodológico, con sus tres dimensiones interdependientes utilizados como categorías analíticas. Fue evidente una debilidad en los protocolos orientados a la atención del paciente hospitalizado, insuficiente integración entre niveles asistenciales y la necesidad de comunicación directa entre lo hospital y la atención primaria. Teniendo en cuenta este resultado propuso un modelo de gestión de la atención, traducido en flujo de la atención con el apoyo de la matriz, consulta de enfermería y contacto telefónico entre las enfermeras. Se cree que con la implementación de este modelo habrá mayor integración entre los niveles de atención, lo que permite una mejora en el proceso de seguimiento del enfermo con tuberculosis, haciéndolos más propensos a adherirse al tratamiento.
\end{abstract}

DESCRIPTORES: Tuberculosis. Enfermeria. Salud pública. Integralidad en salud. Gestión en salud 


\section{INTRODUCTION}

In the past two decades, the democratization of tuberculosis (TB) treatment led to a significant reduction in the mortality and incidence levels of the disease. Nevertheless, TB remains an important global health problem. In 2013, around the world, more than nine million people were affected by the disease and one and a half million died because of the disease. ${ }^{1}$

In Brazil, 70,000 new cases were reported in 2013 only. Treatment compliance represents a challenge and its abandonment is the main responsible for the mortality and relapse rates. ${ }^{2-4}$

The worst cases of the disease are found in the hospital environment, turning this scenario into an essential agent in the diagnosis, management and treatment of the disease. ${ }^{5}$ Considering that most of the cases attended at the hospital will only start the treatment, further approximation with Primary Health Care (PHC) is inevitable.

Therefore, to attend to the TB patients, the principles of integrality and universality need to be appropriated immediately, which take the form of articulation of health actions and services, ${ }^{6}$ respectively, looking for mechanisms to facilitate this process beyond the bureaucratic structures.

In that sense, as an alternative for the organization of care, care management is a possibility, with technologies to act on the individuals' singularities and continuing or momentary needs, aiming for the reestablishment of their wellbeing. Care management can be translated as the way in way in which the care process presents itself in the health organizations, highlighting the interaction among the stakeholders in the process. ${ }^{7}$

Hence, the objective in this study was to propose a Tuberculosis Care Management model focused on the hospital discharge, aiming for the establishment of bonding, welcoming and accountability in the construction of integral care for TB patients hospitalized in the study context, with a view to promoting treatment compliance.

\section{METHOD}

A qualitative intervention research ${ }^{8}$ was undertaken, using the Theory of Nursing Praxis Intervention (TIPESC) in collective health to capture and intervene in the objective reality of the phenomena. ${ }^{9}$ This method presents the analysis of the objective reality in three interdependent dimensions: structural (legal apparatus of society, public policies in health, education, safety etc.), particular (epidemiological profile of class or social reproduction) and singular (forms of social organization, work relations, access to consumption goods and community life), considered as analytic categories in this study. In the operational development of TIPESC, the following phases were developed: capturing of the objective reality, interpretation of the objective reality and construction of the project to intervene in the reality. ${ }^{9}$

The study scenario was a tertiary university hospital in the city of Curitiba, Paraná (PR), which on average attends to $40 \mathrm{~TB}$ cases per year.

The research received approval under opinion 375.036 from $08 / 27 / 2013$ and the criteria for research involving human beings were complied with, in accordance with National Health Council Resolution 466/2012.

The objective reality was captured through non-structured interviews held with key informants, strategically chosen to reveal the context of the investigated group and who, because of their position, action or responsibilities, had good knowledge of the research problem. ${ }^{10}$ The data were collected between March $1^{\text {st }}$ and May $5^{\text {th }} 2014$.

Those key informants were included in the research who adapted to the intention of the study to set out on the itinerary of the TB patients' hospital discharge, including information from the following actors in the process: users, hospital nurses (who monitor the hospital discharge) and primary care nurses (who receive the users post-discharge from the hospital).

In the user category, those users were selected who were hospitalized at the research hospital with TB and were discharged with monitoring at a primary health care service (UBS) in Curitiba-PR between July 2013 and January 2014, estimated at ten (one third of the average six-month records in the previous years). Five users were reached when excluding deaths, users not contacted because of registration problems and users who did not agree to participate). Users under 18 years of age and who did not live in Curitiba-PR were excluded.

In the category of hospital nurses, the following were chosen as key informants: the nurse from the Epidemiology Service responsible for monitoring the users with this problem and the two nurses working at the Infectology inpatient service, as that service receives most of the cases. As for the PHC nurses, one nurse was chosen from each regional health district in Curitiba-PR, totaling nine. The 
nurse was chosen from the PHC service that received most cases of TB within the district.

The identification information of the research participants was coded, revealing only the category they belonged to: users and/or nurses. The latter were divided between PHC or hospital. Thus, the code U corresponds to user, HN stands for hospital nurse and PHCN for primary health care nurse.

\section{RESULTS AND DISCUSSION}

To interpret the objective reality by means of TIPESC, it was considered that the nurses' discourse would clarify the particular dimension and that the users' discourse would represent the singular dimension. For the structural dimension category, the City of Curitiba-PR was observed, considering its characteristics and health management, as well as the city's organization for TB care.

\section{Structural dimension}

Curitiba is the capital and the largest city in the State of Paraná, with an estimated population of $1,848,943$ inhabitants in 2013 , being $100 \%$ urbanized. ${ }^{11}$ People living in large urban centers, in vulnerable income, housing and food situations, often with numerous families, are considered at a greater risk of getting infected, getting ill and dying of TB. ${ }^{12}$

The Ministry of Health recommends that $70 \%$ of the cases be detected, that $100 \%$ be treated correctly and that $85 \%$ be cured. In addition, treatment abandonment cannot exceed $5 \%$, a rate the National Tuberculosis Control Program (NTCP) finds acceptable. ${ }^{2}$ It is estimated that, in 2013, the Municipal Health Department of Curitiba identified $99.7 \%$ of existing cases and, although the cure rate exceeds the target of $85 \%$, for a long time, the abandonment rate remains a problem. That year, the abandonment rate corresponded to $6.2 \%$, strengthening the need to enhance and develop mechanisms that positively influence the previously determined public policies, such as directly observed treatment (DOT) which, despite demonstrating a positive impact on the results, is already insufficient. ${ }^{13}$

In that sense, within the intended goals, although the city of Curitiba-PR played its role, the problem has not been controlled yet. That led to the recognition that the structural dimension of the TB problem needs coping strategies that act at the interface between the existing policy and the objective reality of the treatment abandonment.

\section{Particular dimension}

As a particular dimension of this study phase, the interviewed nurses presented their experiences and knowledge on the hospital discharge process and the reception of TB users at the UBSs, clarifying countless fundamental issues for the development of the Care Management model developed.

Among the nurses working in care delivery to the users in the hospital context, it could be observed that they consider themselves as supporters in the relation with the users in their discharge process. They serve as emphasizers of the medical orientations, as expressed in the following discourse of the nurses:

[...] the physician discharges, [...] and I, as a nurse, strengthen the orientation the physician gave about the importance of the treatment (HN1).

We repeat the doctor's orientations, because sometimes the patient has comprehension difficulties (HN2).

This fact is regretful. Not only because the nurse's professional space is reduced, but mainly because the users depend on the nurses' information. The reasons for this may include the fact that the nurses are clearer, spend more time on their explanations and are more accessible. ${ }^{14}$ Therefore, abandoning the subsidiarity in the relation with the users is fundamental for the nurses to promote the desired results through the information they provide, that is, the understanding, assimilation and apprehension of the theme addressed.

Overall, the nurses focus on short instructions the users should receive and, even about these orientations, dissonance is perceived in the nurses' concepts and lack of standardization in the procedures, as expressed in the following statements:

[...] as the patient is being discharged he is no longer bacilliferous, so the orientation is that he neither needs to stay isolated nor use a mask (HN2).

[...] depending on the case he goes home using a mask or not (HN1).

With regard to tuberculosis, the nurse's role becomes crucial in the control of the problem, ${ }^{5}$ mainly at the operational level, in direct care, as that professional has the direct opportunity to identify determinants in order to assess situations and administer the individuals' economic and singular situations better for the sake of effective treatment. ${ }^{15}$ Therefore, the knowledge and preparation for this care, as well as the adoption of simple, objective and clear technical standards and protocols are essential for a successful treatment. ${ }^{16}$ 
In PHC, the nurses demonstrate knowing the care flow when they discuss the communication between the hospital and the Municipal Health Department. Nevertheless, it is clear that the PHC nurse attends to the users who directly visit the service, even before any formal indication that the case exists.

[...] normally, the user himself comes here with a forwarding letter to proceed with the treatment (PHCN3).

[...] they generally come with a forwarding letter here for the health service, saying that they have already started the treatment [at the hospital] (PHCN4).

When they are discharged, the TB patients' visits to the UBS are not properly monitored, which can result in their not continuing of the treatment. The formerly hospitalized users should be forwarded correctly to the UBS. ${ }^{17}$

In addition, the main sources of information on the cases the PHC nurses receive are the documents the users themselves bring and, as could be considered, these documents should be sufficient for the nurse who receives the user coming from the hospital to know the entire situation the user is in. Nevertheless, the PHC nurses report countless considerations on the quality of the information presented:

[...] the user brings all of the documentation from the hospital [...] but, when they are in bad sociocultural conditions, they end up losing it, do not know where they left it, making it difficult to receive them because they don't have clear information (PHCN2).

[...] both the verbal and written communication needs to improve [...] because many users are not always able to provide the information needed (PHCN3).

The transition of care between the hospital and the primary care service suffers from a great lack of information after the hospital discharge, negatively affecting the continuity of care. ${ }^{14}$ Therefore, a personalized communication system is essential to monitor this condition. ${ }^{18}$

Thus, it is clear that the problem of the particular dimension permeates the hospital nurses' knowledge and preparation in the management of TB cases, as well as the appropriation of their role as fundamental actors in the relation with the users. On the PHC side, the need for communication and quality of the information coming from the hospital is observed.

\section{Singular dimension}

The users who were hospitalized in the study scenario described their hospitalization and dis- charge experiences and what was verified was that the (singular and institutional) discharge conditions were mutually distinct, as could be verified in the following statements:

\section{[...] when I left the hospital I was already better}

[...] on the day I left, I felt kind of lost, I was very depressed (U4).

[...] they wanted to discharge me but I was feeling very bad, I could neither work nor eat (U1).

The reports evidence that the users' conditions at the moment of discharge were very diverse, ranging from users who felt well and safe to go home to users who considered they were not in the slightest conditions to be discharged, strengthening the understanding that there are countless situations that turn this problem more complex. Therefore, the existence of trained professionals is healthy in order to recognize situations that need intervention to conduct the care appropriately. ${ }^{16}$

It is perceived here, however, that the nurses have little contact with the users at the moment of the discharge. None of the interviewees reports having received information and orientations about their condition and the continuity of the treatment by the nurses:

[...] the physician told me that I needed to come back to pick up the result of a test, but I cannot recall having talked to the nurses [...] (U2).

[...] the nurses only came to dress me up, and even bad willed, because I was still using diapers [...] (U1).

These statements reveal the physician as a core element in hospital care and the users' reference as a source of information, leaving the nurses as supporters of their work and as the executors of the care, such as the physical preparation to go home, a problem also evidenced in the particular dimension, as presented earlier.

Thus, a gap is perceived in the activities of the nurses from the inpatient service studied, which directly influences the treatment continuity and success of the TB cases treated there, as this reflects the future relation between PHC and the user.

In that sense, understanding the intertwining among structure, particularity and singularity (objective reality) permitted an intervention process that allowed the nurses to adjust their conducts and play their role in care for the hospitalized TB patients, also because the planning of discharge is a complex aspect of care and is part of the nursing process. ${ }^{19}$ 


\section{Intervention}

The management of tuberculosis care can recognize and cope with the treatment problems, reducing the probabilities of abandonment and complications, besides approaching the user to the construction of protective processes.

Therefore, the Care Management model was proposed, which takes the form of a care flow that adds the nursing consultation to the hospital dis- charge and the direct communication of the case by the hospital nurse to the PHC nurse, responsible for continuing the case. This model is intended to strengthen the organization of the health service for the sake of better attendance and care to TB patients.

Thus, the care flow to inpatients at the study hospital would start with the diagnosis and notification of the case and would only ends with the guarantee that PHC continues the care after the discharge (Figure 1).

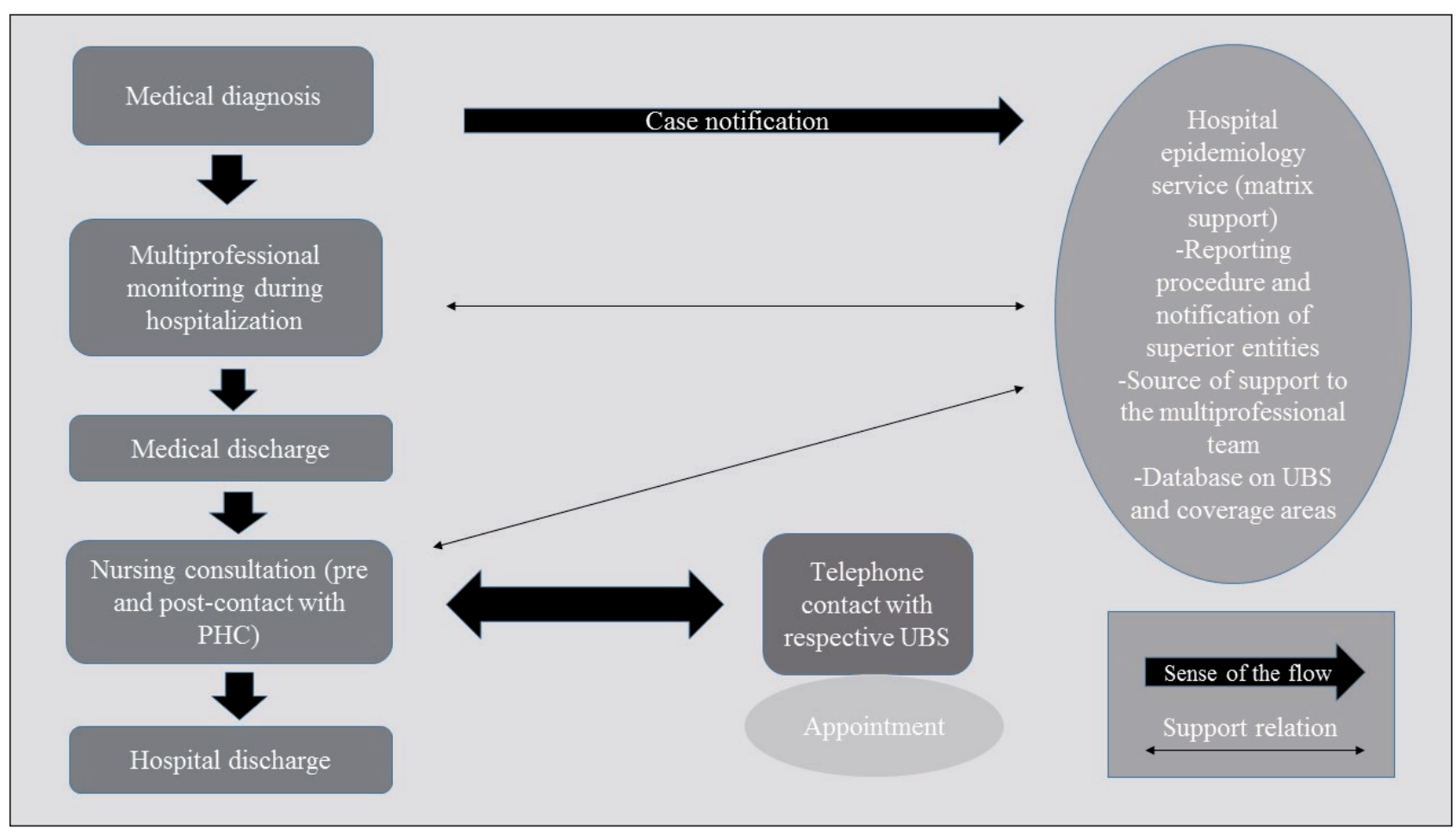

Figure 1 - Proposed care management model of tuberculosis at the university hospital, Curitiba-PR

As shown, this model intends to overcome the existing gap between the hospital and PHC, in which the hospital nurses would become responsible for contacting the PHC nurse, for transmitting all information on the case and for scheduling the user's first appointment at the UBS, making the continuity of the treatment more effective.

The nursing consultation represents a pillar of this model, as that is how the nurses will tighten the relationship with the user. The potential of the nursing consultation as a strategy for effective care offers countless advantages, as it permits the nurses' work in user care, helping to identify problems, needs and weaknesses, which makes it possible to reach decisions, plan and take action in the discharge process. ${ }^{20}$

This care management model also suggests the sharing of responsibilities between the inpatient service and the Hospital Epidemiology Service. In that sense, the nurse from the Hospital Epidemiology Service would serve as matrix support for the nurses from the inpatient services who manage TB cases in their sectors, guaranteeing the rearguard in a personalized and interactive manner. ${ }^{21}$

In concrete terms, telephone contact is established between the hospital nurse and the UBS nurse, with a view to guaranteeing that the latter knows about the case and has access to all information considered necessary to conduct the monitoring. This contact would also permit scheduling the user's first appointment at the UBS.

Hence, the use of this strategy would facilitate the continuity of the treatment in PHC and would reduce the nurses' anxieties at this care level, as the lack of information and surprise at the user's arrival would be factors excluded from the process. 


\section{FINAL CONSIDERATIONS}

Although strategies exist for the control of tuberculosis, the abandonment indicators have been stationary for several years and, despite the important reduction in the number of cases in the last decade, the abandonment rates have not reached acceptable levels yet. This shows that the current health programs are not sufficient and that automated, strict and impersonal methods have not been successful.

Therefore, the management of TB care centered on hospital discharge was considered an alternative to the standard monitoring, as it permits the effective integration with $\mathrm{PHC}$, thus guaranteeing access to and continuity of the treatment.

The achievement of the proposed objective reveals the way in which the care management can contribute to envisage care that more closely approximates integrality for TB patients who need hospitalization in the course of their treatment. The articulation among the health care levels can permit the non-interruption of the treatment and thus promote the reduction of treatment abandonment and treatment compliance.

The success of the proposal can offer uncountable gains, as any reduction in the rates and ratios of a problem like this entails the perception of an actual reversal in care models without problem solving ability, as well as the possibility of a healthier population that can fully exercise its citizenship.

\section{REFERENCES}

1. World Health Organization (WHO). Global tuberculosis report 2014. Geneva (SW): WHO; 2014.

2. Ministério da Saúde (BR). Secretaria de Vigilância em Saúde. Departamento de Vigilância Epidemiológica. Programa Nacional de Controle da Tuberculose. Apresentação padrão 2014. Brasília (DF): MS; 2014.

3. Batalha E, Morosini L. Atenção aos esquecidos. Rev Radis [internet] 2013 Jan [cited 2013 mar 13]; 124(1):816. Available from: http://www6.ensp.fiocruz.br/ radis/sites/default/files/para_o_site_0.pdf

4. Ministério da Saúde (BR). Portal da Saúde. Secretaria de Vigilância em Saúde. Boletim Epidemiológico - Tuberculose no Brasil [internet]. 2014 [cited 2014 set 20]; 44(2). Available from: http://www. vigilanciaemsaude.ba.gov.br/sites/default/files/ Boletim-Tuberculose-2014.pdf

5. Duarte ASC, Braga ALS, Braga SNS. A tuberculose pulmonar em ambiente hospitalar: uma revisão sobre o papel do enfermeiro. Rev Pesq.: Cuid Fundam Online [internet]. 2012 [cited 2013 abr 20]; 4(1). Available from: http://www.seer.unirio.br/index. php/cuidadofundamental/article/view/1437/ pdf_483

6. Alves RS, Souza KMJ, Oliveira AAV, Palha PF, Nogueira JA, Sá LD. Tuberculosis treatment abandonment and comprehensive health care to patients in the family healthcare strategy. Texto Contexto Enferm [internet]. 2012 Jul-Set [cited 2013 abr 20]; 21(3):650-7. Available from: http://www. scielo.br/scielo.php?script=sci_arttext\&pid=S010407072012000300021\&lng=en\&nrm=iso\&tlng=en

7. Cecílio LCO. Apontamentos teórico-conceituais sobre processos avaliativos considerando as múltiplas dimensões da gestão do cuidado em saúde. Interface Comun. Saúde Educ. 2011 Abr-Jun; 37(15):589-99.

8. Tobar F, Yalour MR. Como fazer teses em Saúde Pública: conselhos e ideias para formular projetos e redigir teses e informes de pesquisa. São Paulo (SP): Ed FioCruz; 2004.

9. Egry EY. Saúde coletiva: construindo um novo método em enfermagem. São Paulo (SP): Ícone; 1996.

10. Minayo MCS. O desafio do conhecimento: pesquisa qualitativa em saúde. $12^{\mathrm{a}}$ ed. São Paulo (SP): Hucitec; 2010.

11. Secretaria Municipal da Saúde de Curitiba. Relatório de gestão - $2^{\circ}$ Quadrimestre/2014 [internet]. Curitiba (PR): SMS; [cited 2014 out 05]. Available from: http:// www.saude.curitiba.pr.gov.br/images/SMS_Relat\%C3\%B3rio\%20de\%20Gest\%C3\%A3ol_2\%C2\%BAQuad14_vers\%C3\%A3o\%20final.pdf

12. Paula R, Lefevre F, Lefevre AMC, Galesi, VMN, Schoeps. Why do tuberculosis patients look for urgency and emergency unities for diagnosis: a study on social representation. Rev Bras Epidemiol. 2014 Jul-Set; 17(3):600-14.

13. Secretaria Municipal de Saúde de Curitiba. Relatório anual de gestão - 2013 [internet]. Curitiba (PR): SMS; [cited 2014 mai 05]. Available from: http://www. saude.curitiba.pr.gov.br/images/RAG\%20da \% 20 SMS_SARGSUS_2013_Final.pdf

14. Berendsen AJ, Jong GM, Jong BM, Dekker JH, Schuling J. Transition of care: experiences and preferences of patients across the primary/secondary interface - a qualitative study. BMC Health Serv Res [internet]. 2009 [cited 2014 mar 13]; 62(9): [7 telas]. Available from: http://www.biomedcentral.com/14726963/9/62

15. Oblitas FYM, Loncharich N, Slazar ME, David HML, Silva I, Velásquez D. Nursing's role in tuberculosis control: a discussion from the perspective of equity. Rev Latino-Am Enferm. 2010 Jan-Fev; 18(1):130-8.

16. Melo FAF. Changes in the tuberculosis profile in Brazil: a new reality? J Bras Pneumol. 2010 Jul-Ago; 36(4):397-8.

17. Perrechi MCT, Ribeiro SA. Tuberculosis treatment: integration between hospitals and public health care clinics in the city of São Paulo, Brazil. J Bras Pneumol. 2009 Nov; 35(11):1100-6. 
18. Assis EG, Beraldo AA, Monroe AA, Scatena LM, Gonzáles RIC, Palha PF, et al. The coordination of care for tuberculosis control. Rev Esc Enferm USP. 2012 Fev; 46(1):111-8.

19. Suzuki VF, Carmona EV, Lima MHM. Planning the hospital discharge of patients with diabetes: the construction of a proposal. Rev Esc Enferm USP. 2011 Abr; 45(2):527-32.
20. Oliveira SKP, Queiroz APO, Matos DPM, Moura AF, Lima FET. Temas abordados na consulta de enfermagem: revisão integrativa da literatura. Rev Bras Enferm. 2012 Jan-Fev; 65(1):155-61.

21. Cunha GT, Campos GWS. Apoio matricial e atenção primária em saúde. Saúde Soc. 2011 Out-Dez; 20(4):961-70. 